\title{
Rapid method for distinguishing clonal from polyclonal B cell populations in surgical biopsy specimens
}

\author{
K P McCarthy, J P Sloane, L M Wiedemann
}

\begin{abstract}
The polymerase chain reaction (PCR) was used to detect clonal rearrangements of the immunological heavy chain gene in frozen samples of human lymphoid tissue. DNA sequences in rearranged genes were amplified using oligomeric primers predicted from conserved sequences in the variable $\left(\mathrm{VH}_{\mathrm{H}}\right)$ and joining $(\mathrm{JH})$ regions. On polyacrylamide gel electrophoresis, polyclonal B cell proliferations showed a "smear", probably due to the variable lengths of the diversity $(\mathrm{DH})$ region genes and the $N$ regions separating the $V H$ and DH and JH regions. In contrast, DNA from B cell lymphomas showed a clear single band in eight out of 10 cases. PCR undertaken on germ line DNA from nonlymphoid tumours showed no detectable bands or smears. The method can be completed within one day of biopsy, compared with several days in the case of conventional DNA blot analysis. Furthermore, it is cheaper, simpler, avoids the need for radioactive materials and requires very small amounts of DNA (about $1 \mu \mathrm{g}$ ).
\end{abstract}

Early in the development of the B cell, the DNA of the immunoglobulin (Ig) heavy chain locus undergoes a series of rearrangements. ${ }^{1}$ Firstly, one of many possible diversity $(\mathrm{DH})$ region segments is introduced immediately upstream of one of the six joining $(\mathrm{JH})$ regions. During this processs, terminal deoxyribonucleotide transferase (TdT) inserts nucleotides between the DH and JH segments, thus creating a so-called $\mathrm{N}$ region $\left(\mathrm{N}_{1}\right)$ of variable length and sequence. A second rearrangement brings one of more than a 100 variable $(\mathrm{VH})$ gene segments to lie next to and just upstream from the $\mathrm{DH}$ $\mathrm{N}_{1}-\mathrm{JH}$ locus; $\mathrm{TdT}$ creates a second $\mathrm{N}$ region $\left(\mathrm{N}_{2}\right)$ between $\mathrm{VH}_{\mathrm{H}}$ and $\mathrm{DH}$. Thus the DNA contains a $\mathrm{VH}_{\mathrm{H}}-\mathrm{N}_{2}-\mathrm{DH}_{\mathrm{H}} \mathrm{N}_{1}-\mathrm{JH}$ locus which may then be transcribed into messenger RNA encoding the Ig heavy chain molecule (fig 1). The unique combination of $\mathbf{N}$ regions along with the variation in $\mathrm{DH}$ and $\mathrm{JH}$ region use can be used as a clonal marker of the progeny of the cell. Currently, clonal rearrangement of the Ig heavy chain genes (DNA blot analysis) can only be detected by a laborious, time-consuming protocol which entails the use of radioactive material and relatively large amounts of high molecular weight DNA. ${ }^{2}$

To reduce the time of analysis and size of sample required we used the polymerase chain reaction (PCR) which uses Taq polymerase, a heat stable DNA polymerase from Thermus aquaticus, to amplify a length of target DNA between two known oligomeric DNA sequences. ${ }^{3}$ The process is exponential and results in many millions of copies of the target segment of DNA in only a few hours. In addition radioactive materials are not required.

The PCR technique has been successfully applied to the diagnosis of genetic disease,$^{4}$ to the detection of ras point mutation in various types of cancers, ${ }^{5}$ and to the detection of translocations including the $t(14 ; 18)$ translocation in certain B cell lymphomas ${ }^{6}$ and the product of the $b c r / a b l$ gene fusion in $\mathrm{Ph}$ positive leukaemia. ${ }^{7}$ Until now, however, clonal analysis of many B cell lymphomas has been beyond the scope of the rapid technique due to the uniqueness of the Ig gene rearrangements.

\section{Methods}

Nine cases of B cell lymphoma and one cell line derived from a case of $B$ precursor acute lymphoblastic leukaemia were investigated. These cases were proved to be of B cell lineage on morphological and immunological grounds. They had also all been shown to possess two heavy chain allelic rearrangements by restriction enzyme analysis with Southern blotting (data not shown). As negative controls, four cases of non-neoplastic lymphoid proliferation and two cases of non-lymphoid malignancy were selected. All these had been shown to contain no detectable monoclonal or oligoclonal heavy chain rearrangements (data not shown) by multiple restriction enzyme digests and Southern blotting with a $3.2 \mathrm{JH}$ probe. ${ }^{2}$ The details of the cases are shown in the table.

An oligomeric sequence present in a region common to most $\mathrm{VH}_{\mathrm{H}}$ segments and another complementary to all JH segments were selected as primers. ${ }^{89}$ To analyse BCL2 rearrangements the same JH primer was used, together with a primer complementary to the major breakpoint region of BCL2 (generously donated by Dr L Hiorns). ${ }^{10}$

All samples were biopsy specimens, snap frozen in a beaker of isopentane immersed in liquid nitrogen. DNA was extracted by proteolysis and phenolchloroform extraction as previously described. ${ }^{2}$ The $P C R$ reaction mixture consisted of $0.5 \mu \mathrm{g}$ (about $30 \mathrm{pmol}$ ) of each oligomeric primer, $1 \mu \mathrm{g}$ of sample DNA, 5 units of Taq polymerase, $0.5 \mathrm{mmol}$ of a dNTP $\mathrm{mix}, 50 \mathrm{mM}$ TRIS $\mathrm{HCl}(\mathrm{pH} \mathrm{9.0)}, 15 \mathrm{mM}$ $\left(\mathrm{NH}_{4}\right)_{2} \mathrm{SO}_{4}, 3 \mathrm{mM} \mathrm{MgCl}, 50 \mathrm{mM} \mathrm{KCl}$, and
Correspor Dr K P McCarthy, Leukaemia Research Fund Accepted for publication 6 December 1989 
Figure 1

Immunoglobulin heavy chain gene rearrangement is depicted.

Primer 1 5'CTG TCG

ACA CGG CCG TGT

$A T T A C T G$ 3'

(25-mer).

Primer 2 5' AAC TGC

$A G A G G A G A C G G T$

$G A C C$ 3' (22-mer).

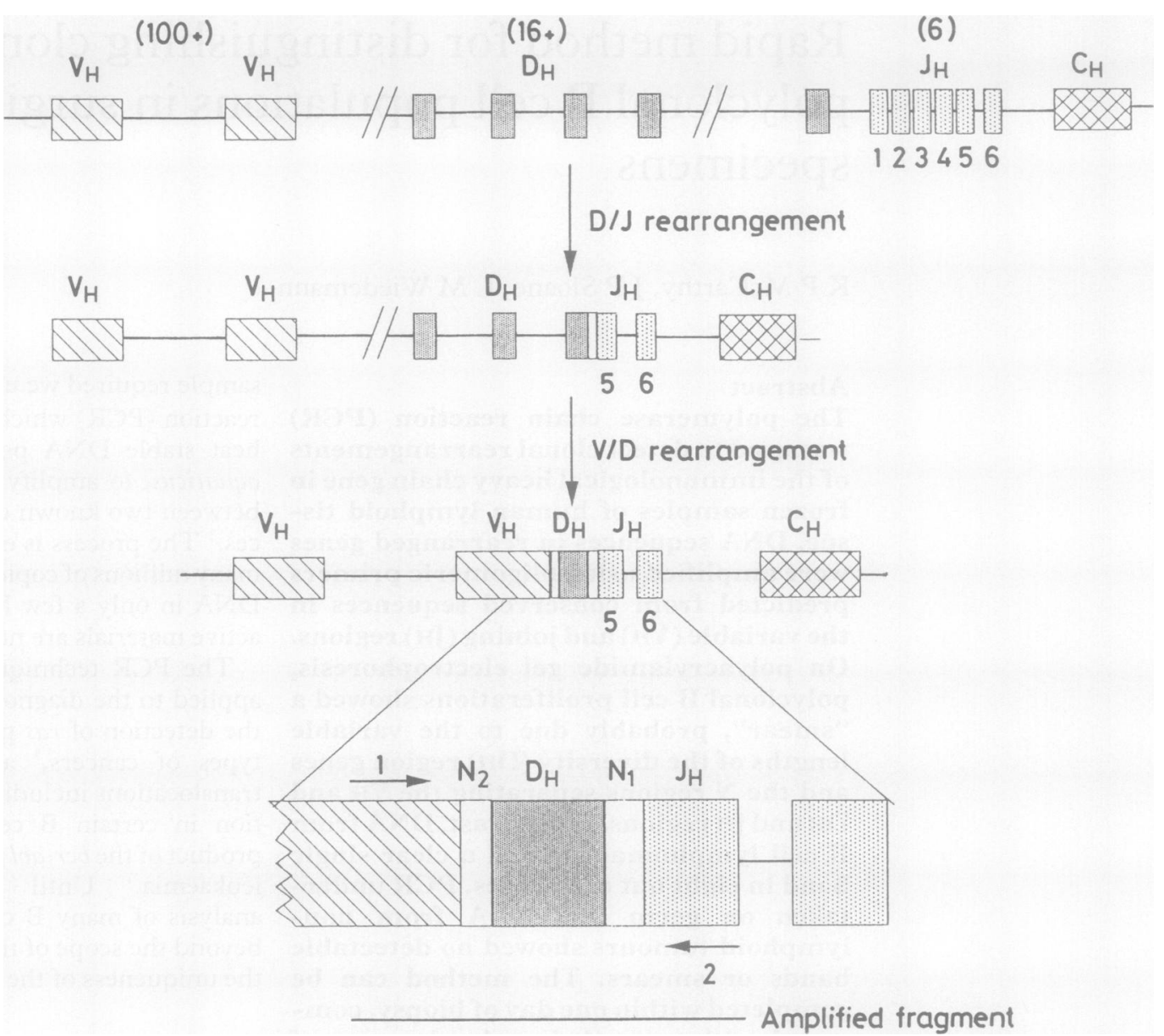

$8.5 \mu \mathrm{g}$ bovine serum albumin in a total volume of $100 \mu \mathrm{l}$.

The first PCR cycle consisted of denaturation of the sample DNA at $93^{\circ} \mathrm{C}$ for five minutes, annealing of the primers at $55^{\circ} \mathrm{C}$ for one minute, then extension of the DNA at $73^{\circ} \mathrm{C}$ for two minutes. Thereafter, the three stages were repeated 30 times, at the same temperatures for one minute each. Aliquots $(40 \mu \mathrm{l})$ were then run on a $10 \%$ polyacrylamide gel at 300 volts for two hours. They were stained with ethidium bromide and photographed under ultraviolet light.

To determine sensitivity DNA from one of the tumours (case 2) and DNA from a histologically normal lymph node were mixed and subjected to PCR as above.

\footnotetext{
Figure 2 PCR analysis of heavy chain gene rearrangement. Numbers above lanes refer to case numbers in the table.

Relevant size markers are given in base pairs along the right hand side.
}

\section{Results}

Cases 1-7 contain a clearly visible, single band between 100 and 150 base pairs in length (fig 2 and data not shown). This is because all the tumour cells, being the progeny of a single cell which has undergone Ig heavy chain rearrangement possess $\mathrm{N}$ and $\mathrm{DH}$ combinations of the same sequence and, therefore, length. In addition, case 8 contains a less intense band not seen in any of the negative controls (fig 2). None of these eight samples was positive when analysed by PCR for rearrangement of BCL2 in the major breakpoint cluster region.

Tumour samples 9 and 10 are negative. Interestingly, one of these (case 10) was positive for BCL2 rearrangement as analysed by PCR (table). All of the control samples of non-neoplastic lymphoid tissue show only a "smear", presumably due to variations in length of $\mathrm{N}$ regions and $\mathrm{DH}$ segments (fig 2 and data not shown).

The sensitivity results are shown in fig 3 . A single discrete band is present down to the point at which tumour DNA comprises only $5^{\circ}{ }_{0}$ of the total.

\section{Discussion}

The technique we have described increases the scope for determining the clonality of B cell proliferations by PCR. It depends on the fact that only in a clone will the rearranged portion of the Ig heavy chain genes ( $\mathrm{VH}-\mathrm{DH}-\mathrm{JH}$ ) be of identical length in all cells. The method has several advantages over conventional DNA 
Clinical and molecular details of samples analysed

\begin{tabular}{|c|c|c|c|c|c|c|}
\hline Case No & Diagnosis & Sex & Age & DNA blot analysis & $I g-P C R$ & $B C L 2$ \\
\hline $\begin{array}{r}1 \\
2 \\
3 \\
4 \\
5 \\
6 \\
7 \\
8 \\
9 \\
10 \\
11 \\
12 \\
13 \\
14 \\
15 \\
16\end{array}$ & $\begin{array}{l}\text { Cell line derived from B precursor ALL (REH) } \\
\text { Malignant lymphoma, small lymphocytic } \\
\text { Malignant lymphoma, diffuse, small cleaved cell } \\
\text { Malignant lymphoma, small lymphocytic, plasmacytoid } \\
\text { Malignant lymphoma, follicular, predominantly small cleaved cell } \\
\text { Malignant lymphoma, follicular, predominantly small cleaved cell } \\
\text { Malignant lymphoma, small lymphocytic } \\
\text { Malignant lymphoma, follicular, mixed small cleaved cell and large cell } \\
\text { Malignant lymphoma, diffuse, large cleaved cell } \\
\text { Malignant lymphoma, diffuse, mixed small cleaved cell and large cleaved cell } \\
\text { Non-specific follicular hyperplasia } \\
\text { Dermatopathic lymphadenopathy } \\
\text { Angiofollicular hyperplasia } \\
\text { Non-specific follicular hyperplasia } \\
\text { Embryonal rhabdomyosarcoma } \\
\text { Adenocarcinoma }\end{array}$ & $\begin{array}{l}\mathbf{M} \\
\mathbf{M} \\
\mathbf{M} \\
\mathbf{F} \\
\mathbf{M} \\
\mathbf{M} \\
\mathbf{F} \\
\mathbf{M} \\
\mathbf{F} \\
\mathbf{F} \\
\mathbf{M} \\
\mathbf{M} \\
\mathbf{M} \\
\mathbf{M} \\
\mathbf{M}\end{array}$ & $\begin{array}{r}42 \\
59 \\
50 \\
52 \\
61 \\
17 \\
48 \\
47 \\
71 \\
64 \\
20 \\
15 \\
41 \\
8 \\
42\end{array}$ & $\begin{array}{l}\mathbf{R} / \mathbf{R} \\
\mathbf{R} / \mathbf{R} \\
\mathbf{R} / \mathbf{R} \\
\mathbf{R} / \mathbf{R} \\
\mathbf{R} / \mathbf{R} \\
\mathbf{R} / \mathbf{R} \\
\mathbf{R} / \mathbf{R} \\
\mathbf{R} / \mathbf{R} \\
\mathbf{R} / \mathbf{R} \\
\mathbf{R} / \mathbf{R} \\
\mathbf{N C} \\
\mathbf{N C} \\
\mathbf{N C} \\
\mathbf{N C} \\
\mathbf{G} / \mathbf{G} \\
\mathbf{G} / \mathbf{G}\end{array}$ & $\begin{array}{l}+ \\
+ \\
+ \\
+ \\
+ \\
+ \\
+ \\
+ \\
- \\
- \\
- \\
= \\
- \\
- \\
-\end{array}$ & $\begin{array}{l}- \\
\overline{-} \\
\overline{-} \\
\overline{-} \\
\overline{-} \\
\overline{-} \\
\overline{-} \\
\pm \\
- \\
- \\
- \\
- \\
-\end{array}$ \\
\hline
\end{tabular}

Lymphomas are classified under the Working Formulation. ${ }^{14}$ All are CD19 positive, CD2 negative, and show light chain restriction.

Ig-PCR = PCR analysis of the VH-DH-JH rearrangement of the heavy chain gene; BCL2 = PCR analysis of the $t(14 ; 18)$ translocation; $R / R=$ both alleles show monoclonal rearrangement; $\mathrm{NC}=$ neither allele shows clonal rearrangement, $\mathbf{G} / \mathbf{G}=$ both alleles in germline configuration.

blot analysis. Firstly, it requires only $1 \mu \mathrm{g}$ of DNA, whereas about $10 \mu \mathrm{g}$ are needed for restriction enzyme analysis. Consequently, more tissue is available for morphological and immunological study. Secondly, the quality of the DNA needed is much less than for restriction enzyme analysis where high molecular weight DNA is a prerequisite. This opens up the possibility of studying formalin fixed, paraffin wax embedded material where the DNA is often greatly degraded. Thirdly, a result can be obtained within one day of biopsy, compared with the several days required for existing methods. Our observations indicate that the clone must comprise at least $5 \%$ of the total number of cells in the sample before it is detectable, thus the method we have described is comparable in sensitivity with DNA blot analysis (fig 3).

It is not clear why only one band (or no band in two cases) was obtained even though rearrangement of both alleles could be shown by DNA blot analysis. There are several possible explanations. It may be that the primer complementary to the consensus region of the $\mathrm{VH}$ genes may not bind to all possible $\mathrm{VH}$ genes. A database search, however, suggests that this primer has greater than $85 \%$ homology with more than $95 \%$ of published $\mathrm{VH}_{\mathrm{H}}$ gene sequences. Alternatively, it may be that while both alleles produce a DH-JH rearrangement, in

Figure 3 Sensitivity of $P C R$ analysis of heavy chain rearrangement.

$D N A$ from a $B$ cell lymphoma and from a normal lymph node were mixed in varying proportions to a total of $1 \mu \mathrm{g}$ of DNA and subjected to PCR. Percentage figures along the top refer to the percentage of tumour DNA in the sample. Numbers to the left of the figure refer to the position of the relevant size markers in base pairs.

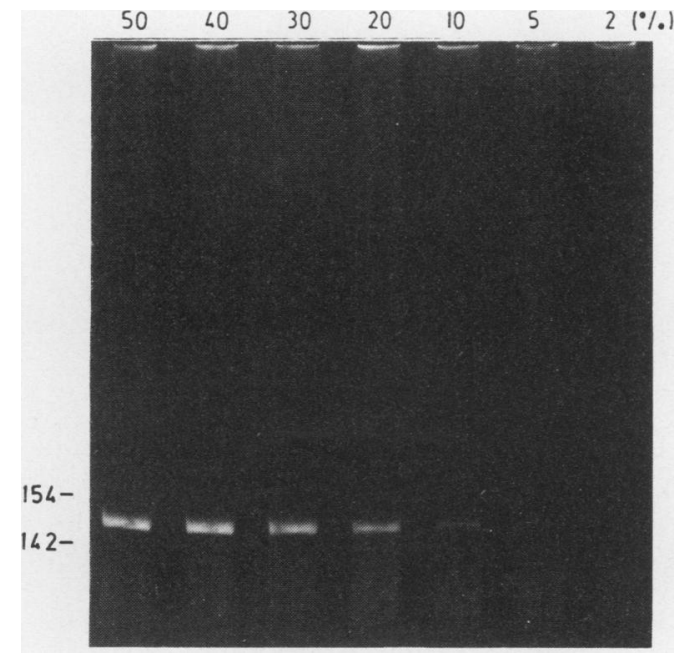

most cases, only one goes on to a $\mathrm{VH}-\mathrm{DH}-\mathrm{JH}$ configuration. Finally, the rearranged genes may be disrupted by chromosomal translocation-for example, $t(14 ; 18)$ or $t(8 ; 14) .{ }^{11}$ We are currently investigating these possibilities.

The $t(14 ; 18)$ chromosomal translocation, which brings the candidate proto-oncogene BCL2 into the Ig heavy chain locus, ${ }^{6}$ can also be used as a clonal marker of certain tumours, particularly follicular lymphomas and large cell lymphomas where it may be found in $95 \%$ and $20^{\circ}{ }_{0}$ of cases, respectively. ${ }^{12}$ If translocations are responsible for our inability to detect some clonal gene rearrangements then the Ig PCR method we have described may be complementary to detecting BCL2 rearrangements by PCR. All of the tumours we studied, which were positive by the former technique, were negative by the latter, although only three cases (cases 5, 6, and 8) are follicular and therefore might be expected to possess the BCL2 rearrangement. Furthermore, one of the two cases which was negative in our analysis for Ig PCR is positive in the PCR analysis for BCL2 rearrangement. We also studied a further three cases with BCL2 rearrangement and all were Ig PCR negative (data not shown). Although the BCL2 translocation was found in only one case (table), its presence cannot be excluded in the remaining cases as roughly $25 \%$ of cases with the $t(14 ; 18)$ translocation involve the minor cluster region of the BCL 2 gene. ${ }^{13}$ Detection of this requires a different oligomeric primer and is presently under investigation.

Clearly, further investigations of the applicability of the Ig PCR technique are required. Its role in diagnosing a greater variety of histological types of $B$ cell neoplasm and in detecting residual disease needs to be clarified. Its usefulness in analysing formalin fixed, paraffin wax embedded tissue also needs to be determined.

On present evidence it is reasonable to suggest that the clonality of a B cell proliferation is first investigated by the Ig PCR technique, possibly in combination with BCL2 rearrangement. In those cases where clonal rearrangements are not found and when sufficient quantities of fresh tissue are available, conventional DNA blot analysis can be performed subsequently with little loss of time. 
We thank Dr L C Chan and Professor M F Greaves for critical BCL2 primer and Dr T Ford for helpful discussions. We also thank Miss B Deverson for secretarial assistance. This research is funded in part by the Leukaemia Research Fund of Great Britain and by locally organised clinical research at the Royal Marsden Hospital.

1 Waldmann TA. The arrangement of Ig and T cell receptor genes in human lymphoproliferative disorders. $A d v$ Immunol 1987:40:247-321.

2 Mizutani S, Ford AM, Wiedemann LM, et al. Rearrangement of immunoglobulin heavy chain genes in human T leukaemic cells shows preferential utilisation of the $\mathrm{D}$ segment $\left(\mathrm{DQ}_{52}\right)$ nearest to the $\mathrm{J}$ region. $E M B O J$ 1986;5:3467-73.

3 Saiki RK, Gelfand DA, Stoffel S, et al. Primer-directed enzymatic amplification of DNA with a thermostable DNA polymerase. Science 1988;239:487-91.

4 Saiki RK, Chang C-A, Levenson $\mathrm{CH}$, et al. Diagnosis of sickle cell anemia and $\beta$-thalassemia with enzymatically amplified DNA and nonradioactive allele-specific oligonucleotide probes. $N$ Engl J Med 1988;319:537-41.

5 Farr CJ, Saiki RK, Erlich HA, McCormick F, Marshall CJ Analysis of ras gene mutations in acute myeloid leukaemia by polymerase chain reaction and oligonucleotide probes. Proc Natl Acad Sci USA 1988;85:1629-33.

6 Lee M, Chang K, Cabanillas F, Freireich EJ, Trujillo JM, Stass $S$. Detection of minimal residual cells carrying the $\mathrm{t}(14 ; 18)$ by DNA sequence amplification. Science
1987;237:175-8.

7 Morgan GJ, Hughes T, Janssen JWG, et al. Polymerase chain reaction for detection of residual leukaemia. Lancet 1989;i:928-9.

8 Yamada M, Hudson S, Tournay O, et al. Detection of minimal disease in haematopoietic malignancies of the Bcell lineage by using third complementarity-deter cell lineage by using third complementarity-determining region (CDR-III)-specif

9 Ravetch JV, Siebenlist U, Korsmeyer S, Waldmann T, Leder $P$. Structure of the human immunoglobulin mu locus: characterisation of embryonic and rearranged J and locus: characterisation of embry

10 Bakhshi A, Wright JJ, Graninger W, et al. Mechanism of the $t(14 ; 18)$ chromosomal translocation: structural analysis of both derivative 14 and 18 reciprocal partners. Proc Natl Acad Sci USA 1987;84:2396-400.

11 de Jong D, Voetdijk MH, van Ommen GJB, KluinNelemans JC, Beverstock GC, Kluin PhM. Translocation $\mathrm{t}(14 ; 18)$ in $B$ cell lymphomas as a cause for defective immunoglobulin production. $J$ Exp Med 1989;169: 613-24.

12 Weiss LM, Warnke RA, Sklar J, Cleary ML. Molecular analysis of the $t(14 ; 18)$ chromosomal translocation in analysis of the $t(14 ; 18)$ chromosomal translocation in

13 Tsujimoto Y, Bashir MM, Givol I, Cossman J, Jaffe E, Croce CM. DNA rearrangements in human follicular Croce CM. DNA rearrangements in human follicular
lymphoma can involve the 5' or the 3' region of the $b c l-2$ gene. Proc Natl Acad Sci USA 1987;84:1329-31.

14 National Cancer Institute sponsored study of classifications of non-Hodgkin's lymphomas. Cancer 1982;49:2112-35. 